\title{
Ewelina Woźniak
}

\section{Dramatyczne konstruowanie twarzy w wybranych utworach Tadeusza Różewicza*}

\begin{abstract}
Woźniak Ewelina, Dramatyczne konstruowanie twarzy w wybranych utworach Tadeusza Różewicza [Dramatic construction of faces in Tadeusz Różewicz's selected poems]. "Przestrzenie Teorii" 21. Poznań 2014, Adam Mickiewicz University Press, pp. 145-165. ISBN 978-83-232-2740-3. ISSN 1644-6763.
\end{abstract}

The purpose of this article is to present Tadeusz Różewicz as a poetic portraitist. Faces very often appear in the poet's works and they play a special role there. The methods that are used to construct them can be grouped into four main categories: 1) a face as a performing subject, 2) a face as an object, 3) a face as a static construct, and finally 4) a face as an element, or metonymy, of human existence and entanglement with reality. In Różewicz's poetry the human face is material and a mirror, but also a universal symbol of the human condition. These faces are usually distorted, decaying, and blurred. They symbolize the disintegration of the world in which human beings have to live. For Różewicz a face is the most condensed image of humanity and an equivalent of a substance in which every external stimulus leaves its mark. The way of using faces as a material and the process of disintegration that is described in detail constitute a dramatic and performative action which implements the objectives of fluid aesthetics, thus showing the moments of transition from meaning to nothingness and the process of erasing meaning.

„Przemiany pisarstwa Tadeusza Różewicza można najprościej w ten sposób ująć, iż poprzez lirykę i dłuższy poemat podążył on najpierw ku szczególnym formom dramatycznym. Od nich ku różnie specyficznym gatunkom prozy. Aż wreszcie po latach prawie trzydziestu praktykowania zawodu pisarskiego jego dzieła układają się w trzy opasłe tomy: Poezja - Dramat - Proza"1. Tak Kazimierz Wyka w swojej napisanej $\mathrm{w}$ latach siedemdziesiątych $\mathrm{XX}$ wieku pracy podsumowuje twórczość Różewicza. Podążając dziś tym tropem, zauważamy, że owe trzy opasłe tomy rozmnożyły się do kilkunastu (Utwory zebrane Wydawnictwa Dolnośląskiego łącznie liczą dziesięć tomów, nie wspominając o tomach wydanych po ukazaniu się serii). Niezwykle intrygującym faktem przy tak ogromnym dorobku pisarskim jest upodobanie Różewicza do wykorzystywania motywu twarzy.

* Artykuł jest zmienioną wersją referatu wygłoszonego na interdyscyplinarnej konferencji naukowej „Tadeusz Różewicz i obrazy” zorganizowanej przez Zakład Literatury i Kultury Nowoczesnej Instytutu Filologii Polskiej Uniwersytetu im. Adama Mickiewicza oraz Komisję Filologiczną Poznańskiego Towarzystwa Przyjaciół Nauk, która odbywała się 2-4 grudnia 2013 roku w Poznaniu.

${ }^{1}$ K. Wyka, Różewicz parokrotnie, Warszawa 1977, s. 83. 
Twarz ludzka była dla mnie i jest krainą, okolicą, krajobrazem, obrazem. Krajobraz twarzy. Twarze rodziców. Twarze rodzeństwa. Twarze obcych. Twarze znajomych z widzenia. Przed kilku laty ujrzałem twarze mieszkańców Moskwy na ruchomych schodach $w$ metro jak na transporterach. Kiedy byłem niesiony do góry, równocześnie $\mathrm{w}$ dół spływała rzeka ludzkich twarzy, kiedy zjeżdżałem w dół, twarze wznosiły się.

Z ogromną zachłannością wpatrywałem się w te twarze. Piękne i brzydkie, stare i młode, interesujące i nijakie. Myślałem „Tysiąc, sto tysięcy, milion twarzy każda inna”. Każda przez kogoś kochana, nienawidzona, oczekiwana. Tak, to największy temat, jaki czeka na mnie od kilku lat ${ }^{2}$.

Tak autor Kartoteki wyraża swój zachwyt nad ludzką twarzą w szkicu pod tytułem - nomen omen - Twarze. Nie jest to jedyny utwór z twarzą w tytule. Najbardziej znane pod tym względem są dwa tomy poetyckie - Twarz z 1964 roku oraz Twarz trzecia z 1968 roku.

W twarzach Różewicza, rozumianych tak, jak pisarz opisuje je w powyższym fragmencie, doszukiwano się powinowactwa $\mathrm{z}$ filozofią Emmanuela Levinasa, który w spotkaniu twarzy drugiego człowieka odnajduje głęboki sens postawy etycznej i odrzuca wszelką przedstawialność czy też „widzialność”, która zakłócałaby przebieg owego poznania. W rozmowach z Philippe'em Nemo autor Całości i nieskończoności stwierdza:

Nie wiem, czy można mówić o „fenomenologii” twarzy, bowiem fenomenologia opisuje to, co się ukazuje. Zastanawiam się również, czy można mówić o spojrzeniu skierowanym w stronę twarzy. Jest ono przecież poznaniem, percepcją. Sądzę raczej, że dostęp do twarzy jest od razu etyczny. Gdy widzi Pan nos, oczy, czoło, brodę drugiego i gdy potrafi je Pan opisać, oznacza to, że zwracamy się do niego jako do przedmiotu. Najlepszy sposób poznania drugiego to taki, w którym nie zauważymy nawet koloru jego oczu! Gdy obserwujemy kolor oczu, nie jesteśmy w relacji społecznej z drugim. To, co jest w sposób specyficzny twarzą, nie sprowadza się do percepcji, mimo że relacja z twarzą może być przez nią zdominowana ${ }^{3}$.

Różewicz wielokrotnie deklarował etyczną postawę wobec poezji i wobec świata w ogóle, ale nie odrzuca na sposób Levinasowski możliwości spojrzenia na twarze. Przeciwnie, często wydobywa twarze z zamazania, z zamglenia, odsłania fragmenty i ślady, rekonstruuje i dekonstruuje po to, żeby zmusić odbiorcę właśnie do patrzenia i zobaczenia prawdy. Nie będę tu przytaczać dyskusji na temat przystawalności teorii Levinasa do różnych aspektów poezji Różewicza, gdyż zdania badaczy są podzielone i nie to jest przedmiotem moich rozważań. Nie ulega jednak wątpliwo-

2 T. Różewicz, Twarze, [w:] tenże, Proza, Wrocław 1973, s. 641.

${ }^{3}$ E. Levinas, Etyka i nieskończony: rozmowy $z$ Philipp'em Nemo, przeł. B. Opolska-Kokoszka, Kraków 1991, s. 49. 
ści, że w przypadku twarzy traktowanych jako portretowy konstrukt poetycki ( $\mathrm{z}$ naciskiem na czynnościowy, a tym samym performatywny aspekt konstruowania), a nie rozumianych jako figura epistemologiczna czy inny byt znaczący, filozoficzna koncepcja autora Całości i nieskończoności nie przystaje do obrazów tu przywoływanych.

Twarz Levinasa zakłada czysto podmiotowe spojrzenie, które pokrywa się z obrazami lub próbami rekonstrukcji twarzy w niektórych utworach poetyckich o tematyce wojennej (na przykład z portretem ojca Arona w wierszu Żywi umierali, o którym będzie jeszcze mowa). Jednakże twarze Różewicza bywają nie tylko podmiotami, ale także tworzywem czy tė̇ ekranem, na którym projektowane są treści, które poeta chce uwidocznić.

[...] twarze w twórczości Różewicza to nie zawsze epifanie Innego, innego człowieka, a w konsekwencji tej etycznej relacji - także Boga ${ }^{4}$.

Jednak nieredukowalność twarzy, tak podkreślana przez Levinasa, zdaje się tylko szlachetnym postulatem, a nie empiryczną rzeczywistością. Epifanii twarzy nie wolno redukować do przedstawienia czy odsłonięcia, ale jednak można to zrobić. Pesymistyczny Różewicz nie ma co do tego wątpliwości: „politycy i generałowie/z wymalowaną na twarzy/drugą twarzą/walczą o zachowanie twarzy/bez twarzy" .

Twarz jest nie tylko podmiotem, ale też pretekstem, metaforą, środkiem i obrazem. Nie bez przyczyny Różewicz w poemacie Tempus fugit deklaruje: „zacząłem atakować Levinasa/który staje się «modny» byłem/zły... że zabrał mi/«twarze» (sprawa do wyjaśnienia)”6. To sa twarze Różewicza, podobne, a jednak zupełnie inne, etyczne i prawdziwe, ale pozostające $\mathrm{w}$ korespondencji $\mathrm{z}$ estetyką i dramatycznością, twarze rozgrywające się, w których fragment jest równie ważny, jak całość i często tę całość reprezentuje.

Te same twarze stały się również jednym z podstawowych pól analitycznych dla badaczy twórczości autora Białego matżeństwa ${ }^{7}$. Biorąc pod uwagę częstotliwość występowania motywu twarzy w utworach autora Kartoteki (zarówno w utworach poetyckich, jak i w dramatach oraz w formach prozatorskich) i - co za tym idzie - wymuszaną poniekąd na badaczach konieczność odwoływania się do owego motywu, niełatwo zna-

${ }^{4}$ J. Potkański, Sobowtór. Różewicz a psychoanaliza Jacques’a Lacana i Melanii Klein, Warszawa 2004, s. 161.

${ }_{5}^{5}$ Tamże, s. 166; cytat z wiersza Różewicza [czarne plamy sq białe...], Płaskorzeźba, s. 33.

${ }^{6}$ T. Różewicz, Tempus fugit, [w:] tenże, Wyjście, Wrocław 2004, s. 72-76.

7 Zob. R. Cieślak, Oko poety: poezja Tadeusza Różewicza wobec sztuk wizualnych, Gdańsk 1999; A. Skrendo, Tadeusz Różewicz i granice literatury: poetyka i etyka transgresji, Kraków 2002; J. Potkański, Sobowtór... i inni. 
leźć w tej kwestii obszar badawczy, który nie byłby jeszcze dostatecznie wyeksploatowany. Niemniej takie płaszczyzny niewątpliwie istnieją. Ogromne możliwości w zakresie analizy problemu Różewiczowskich twarzy stwarza powrót do kwestii, którą Levinas ściśle wiąże z problemem etyki i wykorzystuje wyłącznie $\mathrm{w}$ takim kontekście, a co w przypadku twarzy Różewicza otwiera znacznie szersze i niezbadane pola analityczno-interpretacyjne:

Twarz jest znaczeniem, i to znaczeniem bez kontekstu. [...] twarz jest sensem ze względu na nią samą. Ty to ty. W tym sensie można powiedzieć, że twarz nie jest widziana. Jest tym, co nie może stać się treścią, którą objęłaby nasza myśl; jest niezawieralnością, prowadzi nas poza [podkr. - E.W.]

To, co „nie jest widziane”, „niezawieralność”, i to, co „poza”, zarysowują obszar ciekawy nie tylko z punktu widzenia etyki, ale również z perspektywy estetyki. Potwierdza to sam Różewicz w wierszu $W$ teatrze cieni (Twarz), wskazując na źródła swojej poezji:

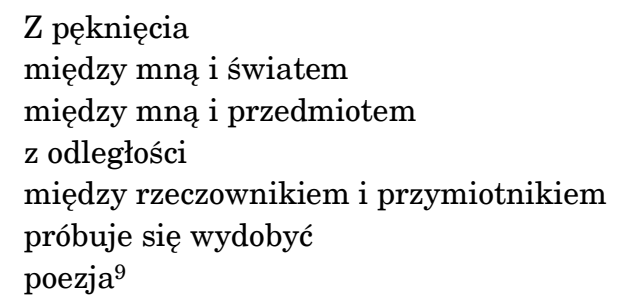

W cytowanym fragmencie szkicu Twarz Różewicz przedstawia tytułową twarz ludzką jako zwierciadło, uniwersalny symbol postawy człowieka wobec świata, ale przede wszystkim - jako tworzywo poetyckie. Twarz dla Różewicza jest najbardziej skondensowanym obrazem człowieczeństwa, odpowiednikiem plastycznej masy, w której każdy zewnętrzny bodziec pozostawia swój ślad. Z tej samej masy poeta rzeźbi dramatyczne anty-portrety, które już w momencie tworzenia ulegają rozpadowi. Jego twarze zwykle bywają zamazane, niewyraźne, zniekształcone. Nierzadko stają się fragmentem, będącym metonimią człowieka. Sposób wykorzystywania twarzy jako tworzywa oraz proces rozpadu są dramatycznym i performatywnym działaniem ukazującym graniczne momenty przechodzenia bytu w nicość oraz wymazywanie znaczenia. Różewicz tworzy metafizyczne fantomy.

Analizy twarzy w utworach autora Kup kota w worku skupiają się przede wszystkim na walorach korespondujących z Różewiczowską koncepcją poezji Prawdy, nierzadko nazywając Różewicza antyestetą. Tym-

8 E. Levinas, Etyka i nieskończony..., s. 49-50.

9 T. Różewicz, Twarz, Warszawa 1966, s. 45. 
czasem sam poeta twierdzi, że „nie ma antyestetyki. A w każdym razie ja jej nie uprawiam. Jest natomiast nowa estetyka, lub jej poszukiwania"10. Przedkładanie etyki nad walory estetyczne wymusza przewartościowanie tych ostatnich, jednakże nie oznacza całkowitego porzucenia piękna na rzecz prawdy. Postuluje raczej ich zjednoczenie ${ }^{11}$. Autor Niepokoju podkreśla, że sztuka i etyka to „dwa wątki, dwie przędze, z których utkano jedną tkaninę"12.

Sposoby przedstawienia twarzy u Różewicza wpisują się w założenia estetyki antybinarnej, estetyki płynnej, rezygnującej z tradycyjnych binarnych opozycji piękno - brzydota, dobro - zło, pozostawiają jednak opozycję prawdy i kłamstwa. Napięcie, które powstaje na skutek różnicy potencjału opozycji binarnych i antybinarnych, ma charakter stricte dramatyczny. „Mnie o to chodziło, żeby przez wiersz było absolutnie widać tę materię dramatyczną, żeby przez wiersz jak przez czystą wodę to, co na dnie się rusza, było widać"13. Niebagatelne znaczenie ma w tym aspekcie funkcjonowanie twarzy jako tworzywa poetyckiego.

W poezji Różewicza zarysowują się cztery kategorie konstruowania portretów. Pierwsza zakłada przedstawienie twarzy jako konstruktu dynamicznego i działającego. Twarz jest w tym wypadku organizmem żywym, wykonawcą czynności. Druga ukazuje twarz jako przedmiot działania, który ulega wpływom różnorakich czynników umiejscowionych na zewnątrz i staje się w ten sposób tworzywem dla podmiotu działającego. Twarz w utworach autora Do piachu funkcjonuje również jako konstrukt statyczny, nieruchomy, zapośredniczony przez odbicie lustrzane, fotografię lub maskę, można by rzec - cudzy. Wreszcie czwarty sposób kreowania twarzy można nazwać tytułem jednego z tomów poetyckich Różewicza - „zawsze fragment”. Podmiot mówiący opisuje w tym przypadku jakiś pojedynczy element, fragment twarzy, który funkcjonuje jako metonimia - człowieka, świata, życia, idei czy anty-idei.

\section{Twarz w działaniu}

Tadeusz Różewicz w Przyroście naturalnym nie bez przyczyny nazywa siebie poetą dramatycznym. W jego utworach poezja, dramat i proza nieustannie się ze sobą przenikają i plączą nie tylko $\mathrm{w}$ formie gatunko-

10 K. Nastulanka, Dużo czystego powietrza, [w:] Wbrew sobie. Rozmowy z Tadeuszem Różewiczem, oprac. J. Stolarczyk, Wrocław 2011, s. 21.

11 Por. R. Cieślak, Oko poety..., s. 23 i n.

12 T. Krzemień, Tramwajem-wierszem do parku-wiersza, [w:] Wbrew sobie..., s. 127.

${ }_{13}$ A. Czerniawski, Tadeusz Różewicz $w$ rozmowie z Adamem Czerniawskim, [w:] Wbrew sobie..., s. 102. 
wej, ale także w używanych przez poetę środkach wyrazu i w sposobach budowania wewnętrznego napięcia. Akcent dramatyczny wyjątkowo mocno pobrzmiewa w wierszach, w których twarz staje się podmiotem działającym. Owo działanie przybiera różne formy i często pojawia się w utworach o bardzo szerokim wachlarzu tematów - od wierszy będących pokłosiem wojennej traumy (Opowiadanie traumatyczne), przez wiersze wspomnieniowe i traktujące o kondycji człowieka (Duszyczka, Koniec) aż po obrazki prezentujące ludzką codzienność (Torba). Punktem wspólnym wszystkich tych utworów jest poruszenie twarzy - rozumiane w sensie dosłownym lub tylko pozorne - które dokonuje się nie tylko w samej treści wiersza, ale również w umyśle odbiorcy. Czytający portrety Różewiczowskich twarzy doświadcza niepowtarzalnego procesu kreacji i destrukcji, gdyż w momencie czytania i rozpoznawania kształtu twarze rozsypują się na jego oczach, ulegając performatywnemu rozpadowi.

Twarze zmieniają się jak w kalejdoskopie, rozpływają się niczym płynne zegary Dalego, znikają jak wysychająca kałuża. Teksty przedstawiające twarz w działaniu są bardzo plastyczne i potęgują wrażenie, że twarze w nich ukazane są organizmem, który samoistnie zmienia kształty, często aż do całkowitego samounicestwienia. Taki efekt poeta uzyskał dzięki zdynamizowaniu opisu twarzy poprzez nagromadzenie czasowników i przymiotników odczasownikowych, które pojawiają się raz za razem i zmuszają wyobraźnię odbiorcy do szybkiej zmiany ruchomych obrazów, tworząc $\mathrm{w}$ ten sposób fragment dramatycznej - w rozumieniu różnicy napięć - sceny wyciętej z taśmy filmowej. Przykładem tego zabiegu konstrukcyjnego jest wiersz Koniec:

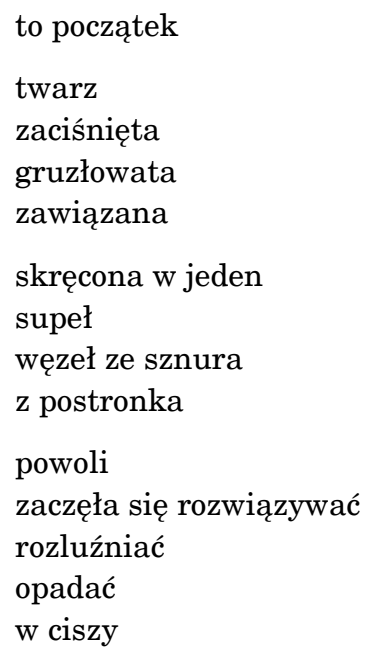




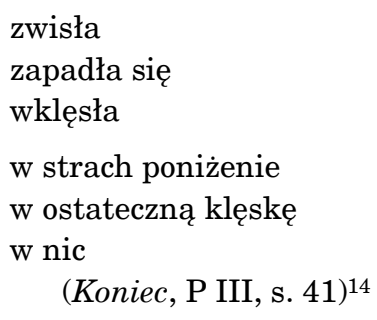

Przyrównana do „węzła ze sznura” czy też „postronka” twarz w cytowanym fragmencie być może jest twarzą wisielca. Twarz nie ma rysów, jest zaciśniętym węzłem pozbawionym powietrza i przestrzeni. Rozwiązywanie się twarzy nie oznacza bynajmniej nadawania jej kształtu, jest zamazywaniem, które postępuje wraz $\mathrm{z}$ wertykalnym bezwładnym opadaniem i rozkładem, aż do momentu, kiedy zostaje „nic”. Owo „nic” nie jest jednak synonimem nieobecności czy braku. Oznacza ostateczną klęskę i brak nadziei, jest obrazem końca, czyli wymazania wszystkiego. Znamienny jest również fakt, że cały proces odbywa się w ciszy. Cisza potęguje odczucie nicości, jest tożsama z milczącą zgodą na unicestwienie.

Niezwykle podobny pod względem wizualnym obraz pojawia się także w Opowiadaniu traumatycznym. Twarz bohaterki lirycznej w momencie rekonstrukcji ulega rozkładowi i rozpada się:

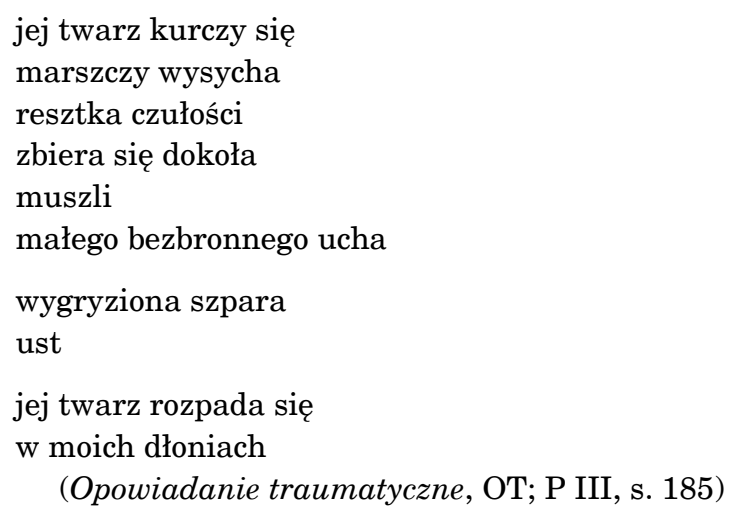

Rozkład jest tu metaforą odejścia bez śladu. Podmiot opisujący twarz kobiety nie może jej odtworzyć w całości, nie jest w stanie powstrzymać jej zanikania. Trzyma w dłoniach twarz zdekompletowaną, z której widzialne pozostają tylko fragmenty ciała i strzępy uczuć - to, co udało się ocalić w słowie.

Również w utworze Duszyczka Różewicz zastosował ten sam sposób obrazowania, jednakże tu fizyczny rozkład twarzy podszyty jest ironią.

14 Źródła cytowanych wierszy - wykaz skrótów: P I - T. Różewicz, Poezja, t. 1, Kraków 1988; P III - T. Różewicz, Poezja. Utwory zebrane, t. 3, Wrocław 2006. 
Twarz nie jest już twarzą, ale fantomem twarzy, groteskową twarzą zepsutej lalki odartą z pozorów życia, czymś, co wywołuje w odbiorcy niepokój - zwłaszcza kiedy na początku wiersza czyta: „tu chodzi o ciebie/ zwłoki to ty”. O kogo chodzi? O czytającego czy o bohatera wiersza?

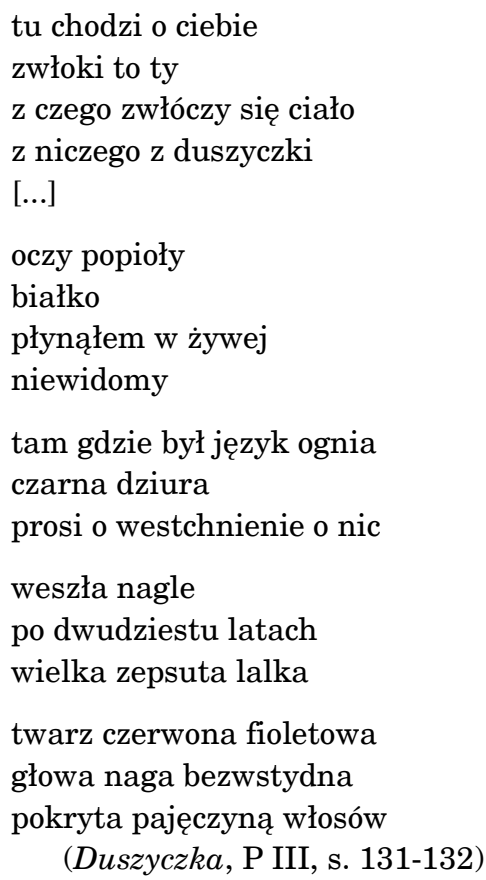

Czytając powyższy fragment wiersza, można odnieść wrażenie, że poeta wręcz epatuje rozkładem, tworząc portret zredukowany do „mięsa”. Takie ujęcie bardzo silnie nawiązuje do barokowego turpizmu i estetyki brzydoty. Obraz jest wyraźny, widzialny, wręcz odsłonięty z ziemskiej powłoki i odsłaniający „wnętrze” - „białko” i „czarną dziurę”, która pochłania światło, wewnętrzny ogień. Przeglądający się w Duszyczce Różewicza czytelnik czuje się jak Dorian Gray spoglądający na swój portret. Pozostając w tym samym kręgu estetycznym, w którym powstało dzieło Oscara Wilde'a, warto przywołać myśl Karla Rosenkranza:

Dla nas wraz ze śmiercią kończy się, co ziemskie; refleks życia pośmiertnego, odbity w kimś, kto skonał, przybiera kształt potwornej anomalii. Ten, który jest już po drugiej stronie, zdaje się podlegać nieznanym nam prawom. Z lękiem przed nieboszczykiem, jako ofiarą procesu rozkładu, i z uwielbieniem dla niego, jako dla rzeczy świętej, miesza się niezgłębiona tajemnica przyszłości15.

${ }^{15}$ Cytat za: U. Eco, Historia brzydoty, przeł. J. Czaplińska, K. Dyjas, A. Gogolin i in., Poznań 2007, s. 312. 
Poglądy Rosenkranza i Różewicza łączy „tajemnica przyszłości”. Autor Estetyki brzydoty pokłada nadzieję w życiu pozagrobowym, poeta natomiast widzi owo „życie po życiu” dość specyficznie. Ironiczna i skądinąd zabawna odpowiedź na pytanie „z czego zwłóczy się ciało/z niczego z duszyczki" rysuje przed przyszłym nieboszczykiem tragikomiczną wizję pozostania na tym świecie pod nieciekawą postacią duszyczki, niepotrzebnej jak zepsuta lalka, przed którą nie wiadomo „gdzie uciec oczami”. Groza rozkładającego się portretu już na wstępie zostaje przełamana, ale trudno tu mówić o jakimkolwiek pozytywnym finale. Gdy tytułowa duszyczka „wyszła”, pozostała tylko słodko-gorzka ironia.

Równie widzialny i jeszcze bardziej namacalny portret możemy znaleźć w wierszu Torba. Twarz, którą widzimy, zyskuje konkretny, choć zaskakujący kształt przedmiotu - damskiej torebki:

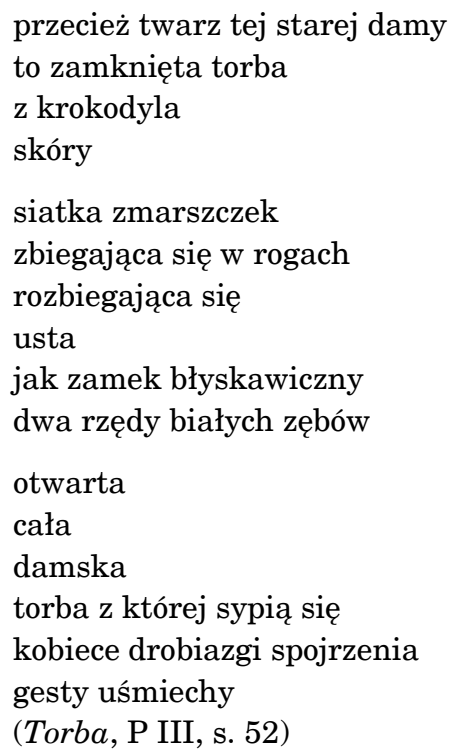

Podążając za myślą podmiotu lirycznego opisującego twarz starszej kobiety, dochodzimy do wniosku, że takie porównanie jest zaskakująco trafne i w wyjątkowo obrazowy sposób przemawia do wyobraźni odbiorcy. Damska torebka - przedmiot, bez którego większość kobiet nie wychodzi z domu - okazuje się najlepszą metaforą kobiecej twarzy, która podkreśla jej żywotność i ruchliwość. „Usta/jak zamek błyskawiczny” otwierają się i zamykają, poruszając siatkę zmarszczek, układających się niczym fałdki na skórze krokodylej. Na tej nieustannie poruszającej się twarzy skupiają się znamiona kobiecości - „kobiece drobiazgi”, jak nazywa je podmiot mówiący, które również nieustannie „sypią się”, jest ich coraz więcej, przenikają się. Całość tworzy dynamiczny i migotliwy obraz twarzy. 
W poezji Różewicza tylko ruch jest otwarciem, a bezwład lub ruch pozorny są równoznaczne z zamknięciem - są przedsionkiem kryzysu tożsamości. [...] Stąd bierze się twarz o zmiennym wyrazie - jeden z głównych motywów w poezji Różewicza, fascynujący jako jedyny obszar, w którym człowiek zdobywa informacje o sobie samym, wnoszący też szeroką paletę skojarzeń plastycznych oraz kolokwialnych określeń, w których twarz staje się synonimem etycznej postawy człowieka $^{16}$.

Otwarcie towarzyszące ruchowi w wierszu Torba zyskuje charakter niemalże dosłowny, gdy podmiot liryczny „otwiera” torebkę, żeby ukazać odbiorcy bogactwo jej zawartości. Spojrzenia, gesty i uśmiechy to tylko trzy - ale wyjątkowo pojemne - słowa, w których zamknięto historię twarzy, jej całą „zawartość”. Różewicz wykorzystuje stereotyp damskiej torebki, żeby ukazać jej podobieństwo do pamięci. Torby mają mnóstwo zakamarków, mieszczą w sobie cały życiowy dobytek, bliskie właścicielkom przedmioty, które wywołują wspomnienia, które się z czymś kojarzą, czasami niepotrzebne, czasami noszone na wszelki wypadek. Torba mieści w środku własny świat i własne historie, pełni tę samą funkcję co „twarz o zmiennym wyrazie”, o której pisze Robert Cieślak, jest obszarem, „w którym człowiek zdobywa informacje o sobie samym”.

\section{Twarz jako przedmiot działania}

Twarze u Różewicza nierzadko funkcjonują jak tworzywo w konstruowaniu świata, jego zminiaturyzowany obraz oraz metonimia podkreślające rozpad i fragmentaryzację, a jednocześnie spajające wiersz poprzez tworzenie portretu. Traktowanie twarzy jako przedmiotu działania nie pozbawia ich podmiotowości. Niejednokrotnie portretowane twarze pełnią jednocześnie funkcje podmiotu działającego i tworzywa kształtowanego przez inny podmiot.

Ciekawym zabiegiem w konstruowaniu Różewiczowskich twarzy jest umieszczenie światła w roli podmiotu działającego. Tak się dzieje między innymi w wierszu Wspomnienie snu $z$ roku 1963. Poeta tworzy w nim jeden z niewielu portretów konkretnie nazwanych - portret Lwa Tołstoja. Nie bez znaczenia jest tu wykorzystanie gry znaczeń z imieniem bohatera lirycznego:

$$
\begin{aligned}
& \text { Śnił mi się } \\
& \text { Lew Tołstoj } \\
& \text { leżał w łóżku } \\
& \text { ogromny jak słońce }
\end{aligned}
$$

16 R. Cieślak, Oko poety..., s. 12. 


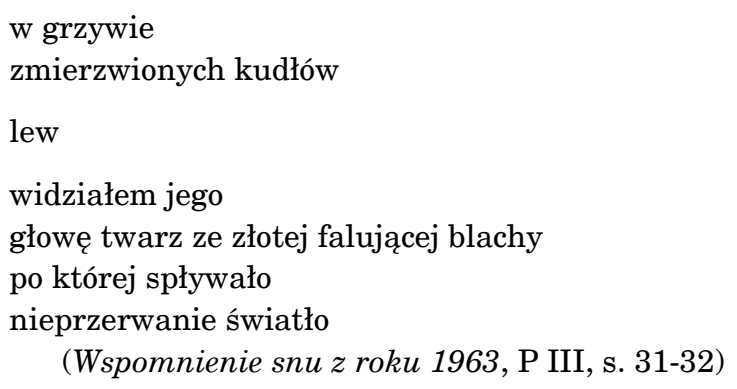

Twarz Lwa - figura silnie zakorzeniona w kulturze i bogata w znaczenia (często przeciwstawne); w mitologiach wielu kultur łeb lwa symbolizuje słońce, ogień i dar „wszystkowidzenia”, „zwycięstwo światła nad ciemnością", również symbol Chrystusa i zmartwychwstania, ale również zła uosabianego przez szatana ${ }^{17}$ - jest centrum kompozycyjnym utworu, słońcem i tarczą z falującej blachy, która odbija światło, ale równocześnie jest tworzywem modelowanym przez światło, które „spływa nieprzerwanie”, gaśnie i rozlewa się na podmiot liryczny - obserwatora.

Światło u Różewicza pojawia się zazwyczaj w towarzystwie cienia, nigdy nie jest czystą światłością oblewającą obserwowany przedmiot, gdyż bezpośrednie patrzenie $\mathrm{w}$ światło pozbawia umiejętności widzenia. Nie możemy patrzeć prosto w słońce - wypełniająca pole widzenia jasność oślepia, przysłania wszystko poza samym światłem, dlatego cień jest konieczny, aby nadać kształt obserwowanej rzeczywistości i tym samym odzyskać możliwość - lub raczej cień możliwości - epistemologicznego poznania ${ }^{18}$.

W świetle poeta odnajduje - rzec by można - praprzyczynę sytuacji lirycznej.

Zrozumiałe, że poezja, dla której wzrok stanowi podstawowy zmysł, zdolny do określenia podstaw istnienia świata i człowieka, dociekać będzie istoty światła. Śledząc wszelkie jego przejawy, przyzna, że światło i cień mają zdolność wydobywania kształtów oraz że w świetle tkwi istota bytu, jeśli przez byt rozumieć to, co dostępne jest naocznemu poznaniu ${ }^{19}$.

Z tego względu twarz Lwa również musi zgasnąć i pogrążyć się w cieniu, aby patrzący mógł zobaczyć to, co Lew kryje w swoim wnętrzu. Światło znika nagle i roztapia się w czerni, poprzez gwałtowną zmianę optyki, pozbawioną półcieni: „zgasł/poczerniał/a skóra jego rąk i twarzy/ - była szorstka/spękana/jak kora dębu”. „Chropawość” pochłania światło ${ }^{20}$,

17 Zob. W. Kopaliński, Stownik symboli, Warszawa 2006, s. 191-194.

18 Zob. A. Krajewska, Dramatyczna teoria literatury. Zarys problematyki, Poznań 1999, s. 196-213; R. Cieślak, Oko poety..., s. 16-23.

19 Tamże, s. 21.

20 Por. A. Krajewska, Dramatyczna teoria literatury..., s. 200-201. 
ale nie zmienia go w całkowitą ciemność. Zostaje zamknięte w kokonie, zasklepione niczym lawa wulkaniczna, by za chwilę się wyzwolić. Ogień-Lew zmartwychwstaje w świetle, które rozsadza rysy i pęknięcia kolejnego rozpadającego się bytu:

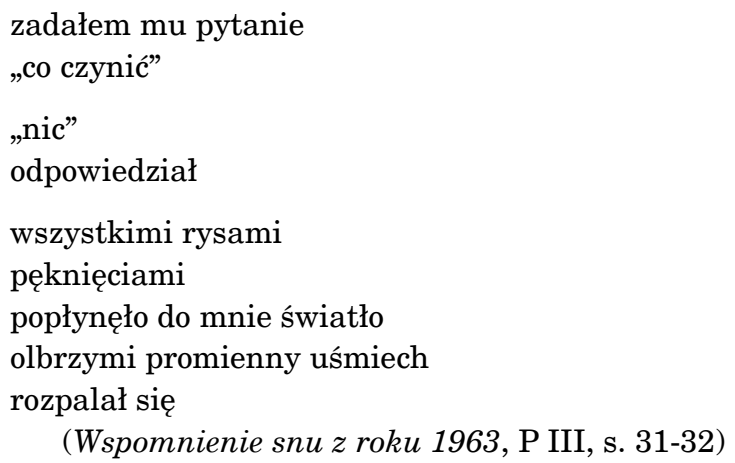

Twarz Lwa Tołstoja rozpływa się w przysłaniającym ją świetle, ale nie zostaje wymazana. Wspomnienie snu $z$ roku 1963 pozwala na specyficzne pojmowanie procesu rozpadu, ściśle powiązanego z aktem tworzenia. Przedmiot działania (twarz) zmienia się w podmiot działający (światło), które promieniuje na obserwatora, w pewnym sensie obierając sobie nowy obiekt kreacji.

Działanie w portrecie Tołstoja przybiera postać zrównoważonej destrukcji i tworzenia, podobnie jak w wierszu [Z czarnych tapek karakułowych obwisty worek...]. Tu twarz także się rozpada, ale ów proces destrukcyjny lub - lepiej - dekonstrukcyjny łączy się z konstruowaniem i przekształcaniem twarzy przez ingerencję zewnętrzną: ugniatanie, inkrustowanie, zasuszenie.

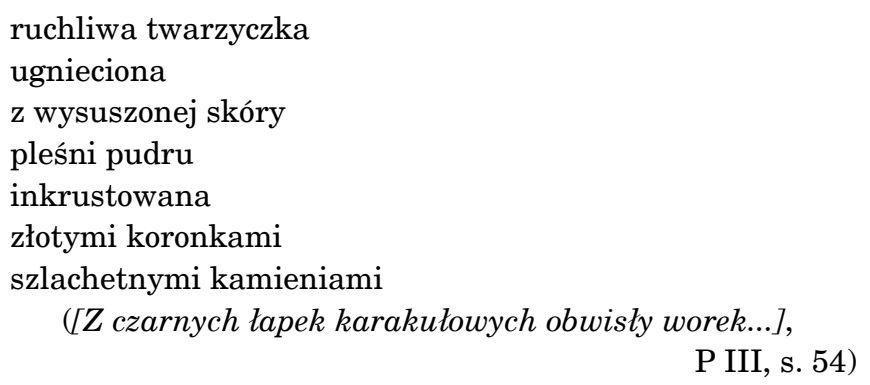

Obraz, który ukazuje nam poeta, jest groteskowy i karykaturalny, nieco przypomina portret twarzy-torby z wiersza Torba. Odwołuje się bezpośrednio do estetyki baroku i barokowego konceptu. Kontrastujące zestawienia słowne: „pleśń pudru”, twarz z „wysuszonej skóry” zdobna „złotymi koronkami” i „szlachetnymi kamieniami” podkreślają przeryso- 
wanie portretu, który wygląda jak maska karnawałowa czy też maska trumienna zakrywające twarz. Szczególnie istotna w tym kontekście jest czynność inkrustowania (późnołacińskie incrustatio, od in-crusto „pokrywam skorupa" 21 jako pokrywanie twardych powierzchni innymi materiałami ${ }^{22}$. Twarz zatem „stwardniała” jak skorupa, a może... jest twarzą żywej mumii, ubraną w „z czarnych łapek/karakułowych/obwisły worek”. Wszystkie te elementy - nie do końca ze sobą spasowane - przedstawiają mistrzowsko naszkicowany, złośliwie zabawny portret starszej, zamożnej damy. Podobnie groteskowy i podszyty lekko złośliwą ironią obraz dandysowatych twarzy przedstawił poeta w Prussian blue. „Twarze z pergaminu/czarne wąsiki/nad otworem gębowym/trzy włoski w brodzie/brodawka na nosie" (Prussian blue, P III, s. 238) ukazane zostały jako kuriozalne fantomy twarzy człowieka, z „otworem gębowym” zamiast ust, wszystkie do siebie podobne.

Konstruowanie twarzy zogniskowane na proces tworzenia czy też odtwarzania (rozumiane jako przeciwieństwo destrukcji, a nie dekonstrukcji) zanikają w utworach, które - mniej lub bardziej - nawiązują do wojennej traumy. Twarze przedstawiane $\mathrm{w}$ tego typu wierszach pokazują przede wszystkim nieodwracalność rozpadu, który nie jest tylko fragmentaryzacją czy transgresją, ale także wywołanym przez sytuację rozkładem i wymazywaniem. Portrety twarzy są w tym wypadku próbą ocalenia śladu.

Pierwsze wersy opisujące twarz ojca Arona w wierszu Żywi umierali ukazują portret przypominający starotestamentowy obraz starca-patriarchy, który „miał brodę z pleśni i mchu/a głowę z białego światła/które gasło drżąc/nim skonał jadł z dłoni/więdnącymi wargami/i otwierał turkusowe oczy" ( $\dot{Z}$ ywi umierali, P I, s. 28). Śladem nadchodzącego zła w jego twarzy jest gasnące światło. Kiedy zgaśnie, nastąpi całkowity rozpad bez śladu, podobnie jak w Opowiadaniu traumatycznym. Twarz zostanie wymazana, a ojciec Aron dołączy do tych, którzy „z dnia na dzień/ulice brukowali/obrzękłymi głowami”. Ów rozpad może zatrzymać tylko napisanie prawdziwego portretu, takiego, który ocala ślad. Przebijająca spod portretu ojca Arona empatia podmiotu mówiącego (w tym aspekcie wyraźnie spokrewniona z poglądami Levinasa) nadaje obrazowi twarzy charakter na wskroś „uczłowieczający”. Ponadto poeta, opisując twarz, dodaje do niej bardzo istotny szczegół - imię. Różewicz uzupełnia portret ofiary - jednej z wielu - konkretnym słowem-portretem, które jest jedynym własnym, indywidualnym śladem człowieka, pozostającym w pamięci i w zapisie.

${ }^{21}$ Hasło: inkrustacja, [w:] Słownik terminologiczny sztuk pięknych, red. K. Kubalska-Sulkiewicz, M. Bielska-Łach, A. Manteuffel-Szarota, Warszawa 2013, s. 160.

${ }^{22}$ Zob. tamże. 
Imiona traktowane jako ślad pojawiają się także w utworze Białe jak kreda:

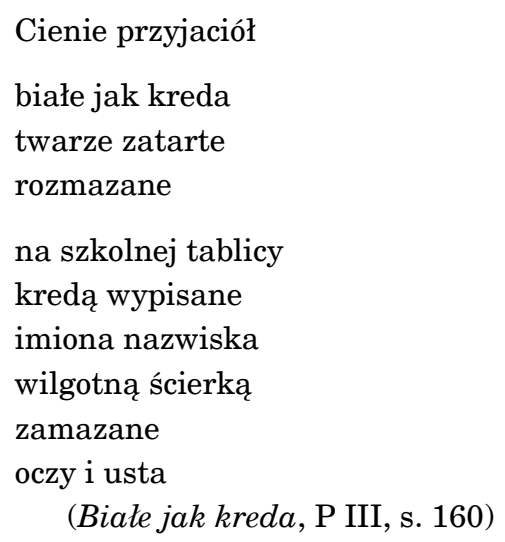

Imiona i nazwiska wypisane kredą na tablicy kojarzą się z latami szkolnymi i wskazują na bardzo młody wiek bohaterów lirycznych wiersza. Ślad kredy bardzo łatwo wymazać, tak jak łatwe okazało się wymazanie czyjegoś życia. Podmiot mówiący nie jest w stanie odtworzyć twarzy swoich przyjaciół. Są dla niego tylko cieniem, siwym śladem na szkolnej tablicy, fragmentem nazwiska lub imienia.

Ślad, który utrata pozostawia w naszej psychice, nie poddaje się biegowi czasu.

Potrafi czas odwracać. Wydaje się, że rana już się zagoiła, tymczasem jakieś drobne wspomnienie i już boli, już krwawi. Wszakże tego, kto odszedł, zastąpić nie można ${ }^{23}$.

Taki portret jest świadectwem pamięci „mimo wszystko”, typem mentalnego „obrazu mimo wszystko"24. Obraz ów ma charakter czysto wizualny ${ }^{25}$, gdyż ślad jest przezroczysty i odsyła do innej, minionej i niemożliwej do zrekonstruowania rzeczywistości sprzed wymazania.

Rola świadka - „ocalonego” - którą przyjmuje poeta, wymaga prawdy twarzy, niemalże dosłownego odrzucenia twarzy „przed” (zwłaszcza jej „człowieczego" charakteru) i odsłonięcia tego, co pozostało.

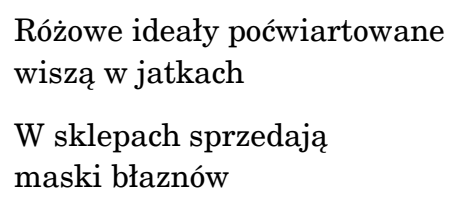

23 B. Skarga, Ślad i obecność, Warszawa 2004, s. 90.

24 Określenie Georges'a Didi-Hubermana, zob. G. Didi-Huberman, Obrazy mimo wszystko, przeł. M. Kubiak Ho-Chi, Kraków 2012 lub tenże, Przed obrazem. Pytanie o cele historii sztuki, przeł. B. Brzezicka, Gdańsk 2011.

${ }^{25}$ Zob. tamże, s. 22. 


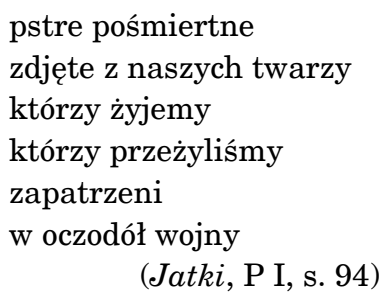

Dawna twarz z „różowymi ideałami” zostaje „zdjęta” (żeby nie powiedzieć „zdarta”) i zastyga, zmienia się w maskę pośmiertną - również rodzaj pozostałości, śladu, tyle że tego, co zostało z dawnych „różowych ideałów”, „poćwiartowanych” przez rzeczywistość wojenną i traumę ocalenia - która zasłaniała „żywą" twarz. Maska fałszuje spojrzenie, a w martwy, będący esencją uprzedmiotowienia człowieka, „oczodół wojny” („oczodół” podobnie jak ,jama ustna” czy „otwór gębowy” nie mogą być częścią podmiotowo rozumianej twarzy ${ }^{26}$ ) trzeba patrzeć wprost, bez filtrów, aby zobaczyć i ocalić ślad.

Różne portrety twarzy jako przedmiotów działania oraz odmienne podmioty działające i kształtujące twarze łączy ponadto jeden dodatkowy aspekt, abstrahujący od tematyki wierszy. Twarze „białe jak kreda”, „twarze z pergaminu” czy twarze „z wysuszonej skóry” przywodzą na myśl tworzywo pisarskie, materiał podlegający zapisowi. To twarze, które kształtowane są podczas pisania i istnieją tylko w zapisie. Pisanie o nich jest - jedynym możliwym - dramatycznym aktem stwarzania, powoływaniem do istnienia lub „odtwarzaniem” istnienia w słowach i fotografią pamięci objawiającą się w obrazach przez te słowa projektowanych.

Pisanie jest podobne działaniu teatralnemu, jest stałym rozgrywaniem sceny, wchodzeniem w dialog z partnerami, w momencie kiedy zaczyna się stabilizować, już się kruszy i rozpada, gdy ogarnia je $\operatorname{czas}^{27}$.

Akt stwarzania jest zatem z góry skazany na ułomność nie tylko ze względu na wpisaną w niego konieczność rozpadu i stopniowe wymazywanie śladów istnienia twarzy, ale także dlatego, że przedstawiane twarze są martwe. Noszą w sobie ślad ruchu, ale są tylko fantomami prawdziwego życia, gdyż ich ruchomość sprowadza się do autodestrukcji, rozkładu i pęknięć. Różewicz w swoich portretowych konstruktach zastępuje niemożność rzeczywistego istnienia permanentnym istnieniem w sferze „pomiędzy” - pomiędzy słowem i obrazem.

${ }^{26}$ Zob. J. Potkański, Sobowtór..., s. 163.

27 A. Krajewska, Dramatyczna teoria literatury..., s. 9. 


\section{Twarze nieruchome}

Jeśli potraktować twarze Różewiczowskie jako „synonim etycznej postawy człowieka”, to niezwykle ciekawie rysują się w takim ujęciu portrety twarzy poety. Podążając za myślą Roberta Cieślaka, bezwład wyzierający z twarzy w wierszu Twarz ta sama byłby znakiem kryzysu tożsamości, tymczasem - w moim odczuciu - nie zawsze tak jest.

Znajdując się na styku postaci wykreowanej, podmiotu tekstu i autobiograficznego ,ja” autorskiego, czytelnik-bohater Różewicza może korzystać ze wszystkich tych tożsamości, a równocześnie żadna z nich nie jest stabilna i ostateczna. Każdą trzeba określać, ponieważ lector w każdej cząstkowej narracji, w której występuje w roli podmiotu, odbiorcy lub obiektu, inaczej się sytuuje wobec rzeczywistości pozatekstowej [...] $]^{28}$.

Niestabilność tożsamości jest pokłosiem nowoczesnego spojrzenia na człowieka uwikłanego w rzeczywistość i wpływa w znacznym stopniu na sposób konstruowania twarzy poety, który znajduje się w centrum tych zmagań. Nie jest to ta sama "twarz o zmiennym wyrazie” z wiersza $Z a$ danie domowe, gdzie „od umiejętności wyrażenia tej zmienności zależy «prawda» poetycka"29. Jest to twarz zmieniona przez odbicie lustrzane, przed którym przestrzega młodego poetę podmiot liryczny Zadania domowego, „twarz ta sama/i zupełnie inna”, pozbawiona treści, niczym maska, która patrzy ze ściany - z odbicia - „twardym/pustym/okiem” (Twarz ta sama, P III, s. 40). Odbicie lustrzane zmienia twarz, tworzy fantom pozbawiony treści, dodatkową anty-tożsamość, niewyraźną i niemożliwą do wypełnienia. Różewicz przeciwstawia sobie zmienną twarz „własną" obcemu - „cudzemu” odbiciu. Pomiędzy tymi dwoma konstruktami twarzy i tożsamości tworzy się pęknięcie, które wytwarza wzajemną interakcję między żywym ciałem a jego fantomem. Każde odbicie twarzy jest zdarzeniem, aktem stworzenia niedoskonałego sobowtóra, będącego przeciwieństwem tożsamości i niekoniecznie wyrazem jej kryzysu.

Interesująco w świetle powyższych rozważań rysuje się problem twarzy przedstawionych na fotografiach, które opisuje poeta. Portrety te nigdy nie są wyraźne, zawsze reprezentuje je jakiś detal - uśmiech, oczy, usta, element ubioru - który zastępuje nie tylko twarz, ale często osobowość i życiorys portretowanego. Motyw fotografii pojawia się już w tomie Niepokój:

Są gruszki złote na talerzu kwiaty i dwie dziewczyny młode

${ }^{28}$ W. Browarny, Tadeusz Różewicz i nowoczesna tożsamość, Kraków 2013, s. 279.

${ }^{29}$ R. Cieślak, Oko poety..., s. 14. 


\author{
Na stole fotografia chłopca \\ jasny i sztywny w czarnym kepi \\ Dziewczyny mają miękkie wargi \\ dziewczyny mają słodkie oczy \\ Przez pokój idzie biedna matka \\ poprawia fotografię płacze
}

Gasna na stole złote słońca

i martwy owoc jej żywota.

(Martwy owoc, P I, s. 37)

Fotografie postawione na stole wyglądają niewinnie. Nic nie wskazuje na to, że są obciążone bagażem traumatycznego doświadczenia. Dopiero działanie - poruszenie fotografii przez matkę-bohaterkę liryczną - wydobywa martwotę tych zdjęć. Gasnące słońca są przeciwieństwem światła, stanowiącego podstawowe tworzywo i warunek widzialności fotografii. Jest zaciemnieniem obrazu-kadru, nie tylko tego widzialnego fotograficznego, ale przede wszystkim wizualnego kadru z życia matki opłakującej martwe dzieci zastygłe na martwych fotografiach.

Zdjęcie może być nie tylko odbiciem wspomnienia, kadrem z przeszłości. Bywa, że jest także obrazem zakrywającym słowo. W wierszu Fotografia podmiot liryczny opisuje portret matki, na który patrzy:

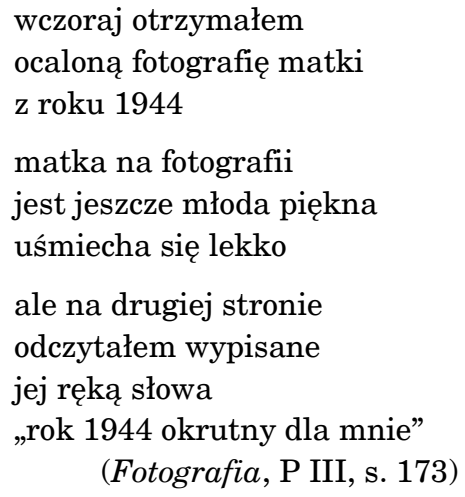

Fotografia przedstawia tylko twarz, nic poza tym. Jest nieprzezroczysta, zakrywa słowa na odwrocie, które wyrażają prawdę. Takie usytuowanie obrazu wobec słowa nasuwa myśl o przewadze etycznego punktu widzenia - wyrażonego przez słowo - nad walorem estetycznym - reprezentowanym przez piękno twarzy na zdjęciu. Zdają się to potwierdzać słowa François Soulagesa, który podkreśla teatralną naturę fotografii i zwraca uwagę na umowność gry pomiędzy jej przedmiotem a światem zewnętrznym: 
"«To», co zostało odegrane”: wszyscy (fotografowany, fotografik i widz) mylą się co do fotografii oraz mogą być zmyleni. Oglądający zdjęcie sądzi, że jest ono dowodem rzeczywistości, podczas gdy stanowi ono wyłącznie oznakę gry. Każde zdjęcie nas okłamuje ${ }^{30}$.

Na pozór obraz zakrywa prawdę nie tylko przedstawianej twarzy, ale również tę zamkniętą w słowie. Śledząc jednakże dalszy ciąg utworu, możemy się przekonać, że to tylko powierzchowne wrażenie:

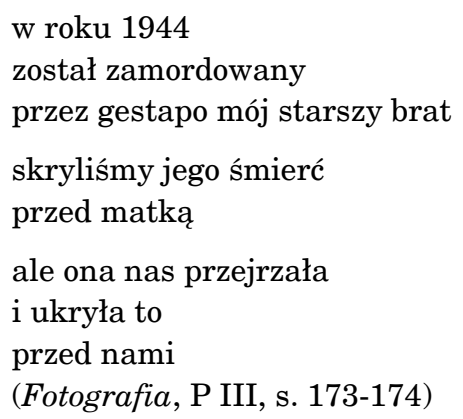

To nie obraz, ale twarz zakrywa słowo. Zdanie zapisane na fotografii jest śladem ręki tej, która została sportretowana (rzeczywistej osoby, nie kreacji) i - jak wynika z wyżej przytoczonego fragmentu - której wolą było jego ukrycie.

[...] fotografia konfrontuje nas z nieświadomością drugiego, z „tym”, co jawi się jako przesunięcie do niemożliwego, stabilnego ,ja”. Odgrywa się ono samo za sprawą dialektycznego układu w obrębie aparatu psychiki. Każde zdjęcie wskazuje na to, iż „to” zostało odegrane, gdyż przed fotografem gra się i jest się odgrywanym. W fotografii pojęcie wolnej woli traci zasadność. Należy je zastąpić grą konieczności i przymusu tworzących życie, teatralnych związków ${ }^{31}$.

Biorąc pod uwagę „grę konieczności i przymusu”, wynikającą nie tylko z sytuacji pozowania, czyli odgrywania zdjęcia, ale także z faktu, że matka bohatera lirycznego wiersza również „odgrywa” spokój i zadowolenie przed swoimi bliskimi, opisana fotografia staje się wielowarstwowym palimpsestem, obrazem nadpisanym nad traumatycznym wydarzeniem, które znajduje swoje odbicie $\mathrm{w}$ geście odręcznego zapisu, dokonanego z kolei nie tylko na odwrocie zdjęcia, ale przede wszystkim na „rewersie” twarzy, pod maską młodości, piękna i uśmiechu. Kiedy podmiot mówiący wykonuje dramatyczne działanie - odwraca zdjęcie - obraz twarzy znika, słowo wymazuje $\mathrm{z}$ fotografii jej pozytywny przekaz i wpisany w nią fałsz, obnaża rzeczywisty portret cierpiącej matki.

${ }^{30}$ F. Soulages, Estetyka fotografii. Strata i zysk, przeł. B. Mytych-Forajter, W. Forajter, Kraków 2007, s. 81.

31 Tamże. 


\section{Zawsze fragment}

„Scena w ciemności, widać jedynie Us ta, w głębi po prawej (patrząc od widowni), około trzech metrów nad poziomem sceny, oświetlona słabym snopem światła z bliska i od dołu, tak by reszta twarzy oraz mikrofon pozostawały w mroku; [...] Gdy na widowni światła zaczynają wygasać, zza kurtyny zaczyna dochodzić głos Ust, które mówią coś niezrozumiale. W ten sposób mówią one jeszcze przez dziesięć sekund po całkowitym wygaśnięciu świateł. Gdy kurtyna idzie w górę, Usta, wciąż niezrozumiale, mówią wybrany fragment tekstu naprowadzający na początek; gdy zaś podniesie się całkowicie i zapanuje odpowiednie skupienie, zaczynają właściwie od"32:

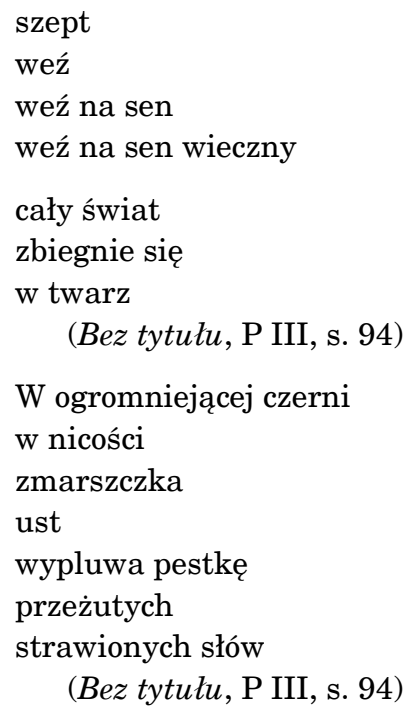

Opis sceny poprzedzający monolog Ust w sztuce Samuela Becketta Nie ja doskonale współgra $\mathrm{z}$ wypowiedzią podmiotu mówiącego w wierszu Różewicza Bez tytułu. Co więcej, czytelnik niezorientowany w twórczości obu autorów mógłby odnieść wrażenie, że są one integralną całością. Co więcej, jeśli oba te fragmenty zestawimy z kolejnym wierszem autora Kartoteki - Moje usta, uzyskamy komentarz do treści wypowiadanej przez Beckettowskie Usta, będący również rodzajem podsumowania sztuki:

Moje usta

które mówiły

prawdę kłamały

${ }^{32}$ S. Beckett, Nie ja, [w:] tenże, Dzieła dramatyczne, przeł. A. Libera, Warszawa 1988, s. 339 . 


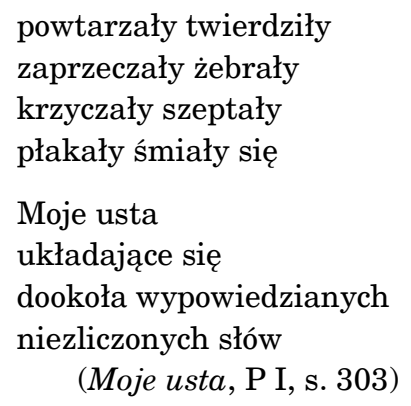

Można by założyć, że te zaskakujące podobieństwa wynikają z inspiracji, jaką Różewicz czerpał z Nie ja, jednakże, biorąc pod uwagę czas powstania obu utworów, takie stwierdzenie może dotyczyć tylko Bez tytutu. Moje usta powstały znacznie wcześniej niż sztuka Becketta. Co zatem sprawia, że wszystkie te utwory są do siebie podobne?

Przede wszystkim wykorzystanie poetyki fragmentu jako metonimii całej postaci. Obaj autorzy wybrali usta, zasłaniając resztę twarzy i tworząc w ten sposób portret zastępczy. Usta odgrywają tu rolę mówiącego rekwizytu, skupiają uwagę widza/czytelnika i wypełniają całą przestrzeń. Mimo widocznego wymazania reszty postaci, usta stają się centrum percepcyjnym odsyłającym do rzeczywistości poza i jednocześnie zasłaniającym ową rzeczywistość. Wypowiadają mnóstwo słów, których nagromadzenie dynamizuje opis i nadaje mu cechy dramatyczne. Ponadto, zarówno w wierszach Różewicza, jak i w sztuce Becketta, otwarcie na zewnątrz utworu oddaje zapis - fragmentaryczny, urywany, pełny pęknięć i przerw - który pozbawia utwory (a przy okazji również ich czytelnika) stabilności interpretacyjnej. Autor Czerwonej rękawiczki idzie jednak krok dalej. Usta $\mathrm{w}$ jego wierszach nierzadko zostają od twarzy oderwane, zmieniają się w „otwór gębowy” (Prussian blue) czy ,jamę ustną" ([czarne plamy sq biate...], s. 33).

Obserwacja przejawów rozkładu i zaniku dąży do innej prawdy niż prawda twarzy - czyli prawda spojrzenia i mowy: do prawdy cuchnącego oddechu z ,jamy ustnej” („usta” mogłyby jeszcze należeć do Twarzy; jama ustna - już w żadnym razie). Powraca obsesyjna Różewiczowska metonimia: zamiast jako źródło uduchowionej mowy, usta wchodzą do poezji w swojej turpistycznej fizyczności ${ }^{33}$.

Przykładów takich metonimii jest więcej. W wierszu Krtań wolności usta należą do świata, nie do człowieka. Są zamknięte obojętnym milczeniem, podczas gdy człowiek mówi nieuduchowioną, fizyczną krtanią, „która błaga/o życie/krtań która porusza się/jak robak/wdeptana w błoto" (Krtań wolności, P I, s. 95).

33 J. Potkański, Sobowtór..., s. 163. 
Komentując Białe groszki, Różewicz stwierdza: „To zwykły zapis komunikatu radiowego, tylko $\mathrm{w}$ pewnym miejscu ja go przeciąłem, jakby podciąłem mu żyły i nastąpił rodzaj liryczno-dramatycznego krwotoku z tych żył. Gdybym ich nie przeciął, tylko do końca naśladował spikera, byłby to zwykły komunikat. Moment przecięcia stworzył sytuację dramatyczną w tym wierszu. Na tym polega jego «otwarcie»"34.

W podobny sposób autor Białych groszków komponuje twarze, przecinając portret $\mathrm{w}$ newralgicznym punkcie i pozostawiając mówiący fragment. W myśl filozofii Jacques'a Derridy można stwierdzić, że opisywane teksty dekonstruują obraz twarzy i znaczą poprzez to, co nieuchwytne, poprzez szczeliny między słowami. Co więcej, zestawienie tekstu dramatycznego ( $w$ sensie gatunkowym) z tekstem poetyckim i możliwość zastosowania tych samych narzędzi analitycznych dowodzi, że materia, z której autor Niepokoju buduje swoje metonimiczne portrety twarzy, ma wielowymiarowy charakter dramatyczny, a poprzez przerwy i pęknięcia również performatywny.

Anna Krajewska w Dramatycznej teorii literatury tak podsumowuje twórczość Różewicza:

Proponując wielowymiarowy kształt pisania, Różewicz zrywa z tradycją pisma

jako linii. Dzieło pisarza domaga się opisania w kategoriach innej estetyki. Estetykę dzieła zastępuje estetyka zdarzenia. Doświadczenie estetyczne okazuje się dla Różewicza zmysłowym doświadczeniem życia i jednocześnie tworzeniem artystycznej kreacji ${ }^{35}$.

Konstruowanie twarzy w utworach Różewicza ma charakter dramatyczny i performatywny. Autor nie tyle portretuje, ile „buduje” twarze z dostępnych fragmentów, dając im własne, często zrekonstruowane życie.

$*$

Wybierając przykłady twarzy opisane w niniejszym szkicu, skupiłam się przede wszystkim na tomikach wydanych w okresie największej poetyckiej płodności poety, czyli mniej więcej do końca lat osiemdziesiątych $\mathrm{XX}$ wieku (wyjątkiem są cytaty $\mathrm{z}$ tomów Ptaskorzeźba, zawsze fragment i zawsze fragment. recycling). Warto zauważyć, że im młodszy zbiór poezji, tym mniej w nim twarzy. W miejsce obrazów pojawiły się słowa. Różewicz dokonał znamiennego i stricte performatywnego gestu - wymazał portrety twarzy ze swoich wierszy.

${ }^{34}$ K. Puzyna, Rozmowy o dramacie. Wokót dramaturgii otwartej, [w:] Wbrew sobie..., s. 46 .

35 A. Krajewska, Dramatyczna teoria literatury..., s. 175. 